\title{
MEMBUMIKAN PANCASILA: UPAYA MEREDAM RADIKALISME DI ENDE-INDONESIA ${ }^{1}$
}

\author{
Oleh: Kristoforus Kopong
}

\begin{abstract}
Abstrak:
Artikel ini bertujuan untuk mendiskusikan secara berimbang kekuatan Pancasila sebagai ideologi bangsa dan dasar negara Indonesia di satu sisi dan kekuatan paham radikalisme di sisi yang lain sekaligus menegaskan bahwa Pancasila adalah adalah dasar negara dan alat pemersatu bangsa Indonesia. Kemajemukaan di Indonesia menuntut adanya alat pemersatu yang sekaligus sebagai alat untuk meredam pelbagai paham-paham yang bertentangan dengan kemajemukan seperti radikalisme. Radikalisme dengan motif dan tujuan untuk apapun dapat merusak tatanan hidup berbangsa dan bernegara maka dari sisi manapun dan di pelosok manapun di Indonesia termasuk di Ende, radikalisme harus dilawan dengan sungguh-sungguh melalui kegiatan membumikan Pancasila. Hasilnya bahwa Pancasila harus tetap dibumikan di seluruh pelosok negeri agar bibit-bibit radikalisme tidak berkembang. Ende harus menjadi contoh bagi bangsa Indonesia bagaimana Pancasila diamalkan sehingga benih radikalisme tidak berkembang.
\end{abstract}

Kata-kata Kunci: Pancasila, membumikan Pancasila, Dasar Negara, Radikalisme.

\section{Pengantar}

$\mathrm{B}$ angsa Indonesia merupakan bangsa yang besar dan memiliki keanekaragaman yang luar biasa. Dalam logika negara-bangsa yang majemuk, Pancasila hadir sebagai dasar negara dan ligatur (pemersatu) dalam perikehidupan kebangsaan dan kenegaraan Indonesia. Namun seiring dengan berjalannya waktu dan pergantian rezim, persatuan dan kesatuan bangsa serta rasa nasionalisme mengalami defisit yang luar biasa. Hasil survei harian Kompas pada tahun 2012 menyimpulkan aspek-aspek yang berkaitan dengan menurunnya nasionalisme tersebut: Solidaritas nasional melemah hingga 60\%, toleransi antargolongan kaya-miskin menurun $(61,4 \%)$, toleransi antarsuku/etnis $(46,5 \%)$, dan toleransi antarumat beragama $(38,9 \%) .^{2}$

Kenyataan di atas menjadi potensi ancaman laten terhadap bangsa Indonesia terutama di era globalisasi yang telah merubah pola hubungan antarbangsa dalam berbagai aspek. Negara seolah tanpa batas (boderless), saling tergantung (independency) dan saling terhubung (interconected) antara satu negara dengan negara lainnya. Situasi ini juga membawa perubahan pada pola dan tata laku bangsa Indonesia dalam hidup berbangsa dan bernegara. Bangsa Indonesia yang dikenal tradisi budayanya yang penuh toleransi, ramah, religius, dan menjunjung tinggi nilai-nilai kesopanan, tiba-tiba berubah menjadi bangsa yang beringas, bahkan tidak segan-segan melakukan kejahatan terhadap kemanusiaan dalam aksi-aksi radikalisme.

Radikalisme ibarat "virus" yang menyerang bangsa Indonesia melalui aksi-aksi teror yang ekstrim. "Virus" ini bahkan sedang menyerang Ideologi Pancasila sebagai imun dan

${ }^{1}$ Artikel ini merupakan pengembangan materi seminar di Aula Tarsisius Gereja Paroki Persiapan St. Marinus Pu'urere, 30 September 2018 dalam Rangka Memasyarakatkan Pancasila: Pilar Kehidupan Berbangsa dan Beragama.

2 Jajak Pendapat “Ancaman Kebangsaan”, Harian Kompas, Senin, 21 Juni 2012. 
jantung pertahanan kehidupan bangsa dan negara Indonesia. Penyebaran virus radikalisme ini berbanding lurus dengan hasil survei yang dilakukan oleh aktivis Gerakan Mahasiswa dan Pemuda Indonesia pada tahun 2006 bahwa sebanyak $80 \%$ mahasiswa memilih syari'ah sebagai pandangan hidup berbangsa dan bernegara. Sebanyak $15,5 \%$ responden memilih aliran sosialisme dengan berbagai varian sebagai acuan hidup dan hanya 4,5\% responden yang masih memandang Pancasila tetap layak sebagai pandangan hidup berbangsa dan bernegara. ${ }^{3}$

Sebagai bangsa yang besar, Indonesia dan Kabupaten Ende khususnya tidak boleh kalah berhadapan dengan paham radikalisme. Pancasila sebagai ideologi bangsa dan dasar negara telah dibuktikan kualitasnya sepanjang sejarah bangsa terutama ketika bangsa Indonesia mengalami masa-masa sulit di era Orde Lama maupun era Orde Baru. Namun, di era globalisasi dengan segala dinamikanya bangsa Indonesia perlu tetap waspada terhadap bahaya radikalisme. Oleh karena itu, uraian ini bermaksud untuk mendiskusikan secara berimbang kekuatan Pancasila sebagai ideologi bangsa dan dasar negara Indonesia di satu sisi dan kekuatan paham radikalisme di sisi yang lain. Hanya dengan cara ini, kita secara bersama dapat menemukan strategi-strategi jitu untuk membumikan Pancasila dan Menghanguskan Radikalisme di bumi Indonesia secara khusus di Ende-Rahim Pancasila.

\section{Eksistensi dan Esensi Pancasila dalam Sejarah Panjang Bangsa Indonesia}

\section{Pancasila dalam proses penemuannya}

Diskusi proses penemuan Pancasila sebagai ligatur (pemersatu) bangsa dan sekaligus dasar negara merdeka, tidak terlepas dari peran besar yang dimainkan oleh Sukarno. ${ }^{4}$ Dalam pidatonya di depan Sidang BPUPKI (Badan Penyelidik Usaha-usaha Persiapan Kemerdekaan Indonesia) pada tanggal 29 Mei - 1 Juni, Soekarno menyebut Pancasila untuk merujuk pada butir-butir pemikiran yang diusulkannya sebagai dasar negara Indonesia merdeka. ${ }^{5}$ Kelima butir pemikiran tersebut, yakni (1) Kebangsaan Indonesia; (2) Internasionalisme atau prinsip perikemanusiaan; (3) Mufakat atau demokrasi; (4) Kesejahteraan sosial; dan (5) Prinsip Ketuhanan yang berkebudayaan. ${ }^{6}$

Usulan pemikiran Soekarno diterima BPUPKI dan dielaborasi lebih jauh oleh Panitia Sembilan. Tugas dan tujuan dari dibentuknya panitia sembilan ini adalah untuk merumuskan dasar negara Indonesia merdeka dan tujuan pembentukan Indonesia merdeka. Dari sidang yang dilaksanakan oleh Panitia sembilan, disampaikan rumusan dasar negara/ rumusan pancasila, disebut dengan Piagam Jakarta (Jakarta Charter). Isi Piagam Jakarta adalah sebagai berikut: (1) Ketuhanan dengan kewajiban menjalankan syariat islam bagi pemeluknya; (2) Kemanusiaan yang adil dan beradab; (3) Persatuan Indonesia; (4) Kerakyatan yang dipimpin oleh hikmat kebijaksanaan dalam permusyawaratan/ perwakilan; dan (5) Keadilan sosial bagi seluruh rakyat Indonesia.

Rangkaian proses penemuan Pancasila ternyata belum berakhir, karena setelah penetapan rumusan dasar negara yang tercantum dalam Piagam Jakarta, pemeluk agama lain (non-islam) dan terutama tokoh-tokoh dari Indonesia bagian timur merasa keberatan dengan

\footnotetext{
${ }^{3}$ Harian Umum Kompas, 4 Maret 2008.

${ }^{4}$ P.J.Suswarno, Pancasila Budaya Bangsa Indonesia, (Yogyakarta: Kanisius, 1993), hlm. 17-38.

5 Ibid., hlm. 66.

${ }^{6}$ Muhammad Yamin, Naskah Persiapan UUD 1945, (Jakarta : PT. Yayasan Prapantja, 1959), hlm. 69-78.
} 
kalimat pada sila pertama, yaitu "dengan kewajiban menjalankan syariat Islam bagi pemelukpemeluknya”. Jika hal ini tidak diperhatikan, maka golongan Kristen dan Katolik lebih suka berada di luar republik. ${ }^{7}$

Demi menjaga persatuan dan kesatuan bangsa Indonesia, tujuh kata di belakang Ketuhanan dihapus dan diganti dengan "Yang Maha Esa", suatu anak kalimat yang kiranya dapat diterima oleh semua pihak. Selanjutnya, PPKI pada tanggal 18 Agustus 1945 memutuskan bahwa Naskah Piagam Jakarta dijadikan UUD RI dengan terlebih dahulu diadakan perubahan pada alinea keempat: Rumusan "Ketuhanan, dengan kewajiban menjalankan syariat Islam bagi pemeluk-pemeluknya" diubah menjadi "Ketuhanan Yang Maha Esa". ${ }^{8}$ Akhirnya rumusan final Pancasila sebagai dasar negara yang sah dan benar adalah: (1) Ketuhanan yang Maha Esa; (2) Kemanusiaan yang adil dan beradab; (3) Persatuan Indonesia; (4) Kerakyatan yang dipimpin oleh hikmat kebijaksanan dalam permusyawaratan /perwakilan, dan (5) Keadilan sosial bagi seluruh rakyat Indonesia.

Dalam proses panjang perumusan Pancasila tentu terjadi lobi-lobi, polemik, dan perdebatan yang sangat alot. Semua hal yang terjadi baik dalam sidang BPUPKI I, BPUPKI II dan juga PPKI merupakan proses pemurnian buah pemikiran para founding fathers. Sikap kenegarawan-an pendahulu memperlihatkan adanya keterarahan pikiran dan kehendak mereka untuk menempatkan pokok persoalan bangsa di atas kepentingan pribadi dan golongan. Kompromi pikiran dan kehendak merupakan cara bijak untuk menemukan alternatif terbaik yang dapat mengakomodir keinginan semua pihak. "Ketuhanan Yang Maha Esa" merupakan sintesis dari antitesis-antitesis pikiran keagamaan semua golongan dari Marauke (kota paling Timur) sampai Sabang (kota paling Barat) dan dari Miangas (pulau paling Utara) hingga Rote (pulau paling Selatan). Rumusan para founding fathers tersebut merupakam par exellence dari upaya untuk memenuhi kebutuhan akan adanya landasan hidup bersama sebagai bangsa yang multikultural.

\section{Kedudukan dan fungsi Pancasila dalam kehidupan berbangsa dan bernegara}

Pancasila yang lahir pada 1 Juni 1945 dan disahkan 18 Agustus 1945 adalah bersifat final dan mengikat bangsa Indonesia. Dalam tata kehidupan berbangsa dan bernegara Pancasila memiliki lima kedudukan dan fungsi, yakni: ${ }^{9}$ Pertama, Pancasila sebagai isi jiwa bangsa. Silasila Pancasila merupakan jiwa (volkgeist) bangsa Indonesia. Isi jiwa bangsa Indonesia adalah kristalisasi dari nilai-nilai budaya yang telah tertanam jauh dan berurat akar dalam pusat kesadaran bangsa. Perwujudan isi jiwa bangsa tampak dalam watak dan kepribadian bangsa Indonesia. Isi inilah yang menjadi corak yang khas bagi bangsa Indonesia, serta merupakan ciri khas yang membedakan bangsa Indonesia dengan bangsa lain. Terdapat kemungkinan bahwa sila secara terlepas dari yang lain bersifat universal yang juga dimiliki oleh bangsa-bangsa lain di dunia; akan tetapi kelima sila Pancasila sebagai satu kesatuan yang bulat dan utuh itulah yang menjadi ciri khas bangsa Indonesia. Bangsa yang tumbuh di atas kepribadian bangsa lain,

\footnotetext{
${ }^{7}$ Mustafa Kamal Pasha, dkk., Pancasila Dalam Tinjauan Historis, Yuridis, dan Filosofis, (Yogyakarta: Citra Karsa Mandiri, 2003), hlm. 32.

${ }^{8}$ Kristoforus Kopong, Membumikan Pancasila, Mengurai Benang Kusut NKRI, (Yogyakarta: WR, 2015), hlm. 14 .

${ }^{9}$ Uraian pemikiran tentang lima kedudukan dan fungsi Pancasila ini, saya mengomparasikan pembahasan M. Aziz Toyibin dan A. Kosasih Djahiri dalam buku Pendidikan Pancasila, (Jakarta: PT. Rineka Cipta, 1997) dan Pembahasan Soerjanto Poespowardojo dalam bukunya Filsafat Sebuah Pendekatan Sosio Budaya, (Jakarta: Gramedia, 1988).
} 
mungkin secara fisik dapat berkembang dan maju, akan tetapi secara psikis kemajuan itu membuat kita merasa teralienasi (asing/gelisah) dalam diri dan bangsa sendiri.

Kedua, Pancasila sebagai pandangan hidup bangsa. Setiap bangsa ingin berdiri kokoh dan mengetahui dengan jelas ke arah mana tujuan yang ingin dicapainya sangat memerlukan pandangan hidup (Weltanschauung). Pancasila merupakan pandangan hidup bangsa Indonesia, kesadaran dan cita-cita moral, kompas pengarah ke mana bangsa Indonesia harus melangkah. Dengan berpegang teguh pada Pancasila bangsa Indonesia mampu memandang pelbagai persoalan yang dihadapinya dan menentukan arah serta cara bagaimana bangsa ini memecahkan persoalan-persoalan itu secara bijaksana. Tanpa berpegang teguh pada Pancasila bangsa ini akan menjadi bangsa yang besar namun terombang-ambing.

Ketiga, Pancasila sebagai ideologi negara. Secara umum ideologi dipahami sebagai sistem gagasan, keyakinan dan sikap yang mendasari cara hidup kelompok, kelas atau masyarakat tertentu (System of ideals, belief and attitudes which underlie the way of life in a particular group, class or cociety). Ideologi Pancasila merupakan keseluruhan sistem gagasan, keyakinan dan sikap yang mendasari cara hidup bangsa dan negara Indonesia. Nilai-nilai yang terkandung dalam Pancasila menjadi ideal, wawasan, dan pandangan yang memberi pendasaran bagi seluruh praksis hidup bangsa dan negara. Seluruh praksis hidup berbangsa dan bernegara merupakan operasionalisasi dari nilai-nilai yang terkandung di dalam Ideologi Negara demi mencapai cita-cita bersama.

Sebagai sebuah Ideologi, Pancasila memiliki kekuatan yang luar biasa karena mengandung 3 dimensi, yaitu: ${ }^{10}$ (1) Realita. Nilai-nilai dasar secara riil hidup di dalam serta bersumber dari budaya dan pengalaman sejarah bangsa. (2) Idealisme. Nilai-nilai dasar yang secara psikologis memberi harapan tentang masa depan yang lebih baik. (3) fleksibilitas. Keluwesan yang merangsang pengembangan pemikiran-pemikiran baru yang relevan, tanpa mengingkari jati diri. Kekuatan tiga dimensi inilah yang menjadikan Pancasila sebagai ideologi yang berakar dan hidup dalam konteks menyejarah.

Keempat, Pancasila sebagai dasar negara. Konsepsi Pancasila sebagai dasar negara Indonesia terkandung maksud, dua aspek pengertian. Pertama, berkaitan dengan fundasi bangunan NKRI. Dengan begitu, mempertahankan NKRI tidak mungkin tanpa mempertahankan Pancasila sebagai dasarnya. Karena itu logika-kausalitasnya "Menjaga keutuhan NKRI berarti mempertahankan Pancasila sebagai dasarnya, sebaliknya menolak Pancasila sebagai dasar berarti merombak total bangunan NKRI. ${ }^{11}$ Kedua, berkaitan dengan kemajemukan entitas seperti suku, agama, ras, dan antargolongan yang membentuk Indonesia, diyakini bahwa Pancasila dasar pijak bersama yang menyatukan aneka perbedaan itu. Nilai-nilai Pancasila merupakan pedoman bersama dan rujukan kolektif dari pelbagai entitas bangsa.

Kelima, Pancasila sebagai falsafat negara. Sebagai filsafat negara (staats filosofi), Pancasila merupakan sistem pengetahuan (epistemologi). Artinya, pertama, secara teoretis rumusan sila-sila Pancasila merupakan hasil refleksi kritis dan rasional tentang kenyataan budaya bangsa, dengan tujuan untuk mendapatkan pokok-pokok pengertiannya yang mendasar, mendalam dan menyeluruh (absrak-umum-universal). Kedua, Secara sistematika lima sila Pancasila bukan merupakan kumpulan sila-sila yang berdiri sendiri, melainkan "panca tunggal"

${ }^{10}$ Oetojo Oesman dan Alfian (peny.), Pancasila Sebagai Ideologi, (Jakarta: BP7 Pusat, 1991), hlm. 40.

${ }^{11}$ Kristoforus Kopong, Berselancar ke Ranah Konstitusi, Mengenal dan Memahami Konstitusi Indonesia (UUD 1945) dari Proses Pembentukan sampai dengan Perubahannya, (Yogyakarta: WR, 2017), hlm. 106. 
menggambarkan suatu kesatuan organis (sistem). Karena itu, jika salah satu di antara kelima sila itu hilang, maka hilanglah makna kesatuannya yang terkadung di dalam Pancasila. Ketiga, secara hirarkhis susunan sila-sila Pancasila mengandung makna bahwa sila di atas mendasari sila-sila di bawahnya dan sila di bawah merupakan realisasi dari sila di atasnya. Jadi, kelima sila dari Pancasila tidak terpisah, melainkan membentuk suatu sistem filsafat atau gestalt (kesatuan yang berarti).

Dalam kedudukannya yang strategis dan fungsinya kompatibel Pancasila mampu mempersatukan bangsa Indonesia dalam wadah NKRI yang diproklamasikan 17 Agustus 1945. Itulah sebabnya, kalau ada gagasan amandemen UUD 1945, haram hukumnya untuk menyentuh Pembukaan atau Preambul (Mukadimah) UUD 1945.

\section{Artikulasi dan implementasi Pancasila dalam lintasan sejarah bangsa Indonesia}

Setiap masa memiliki paradigama yang berbeda dalam mengartikan dan mengimplementasikan Pancasila. Hal ini tentu berpengaruh langsung terhadap kebijakan dan keputusan yang dibuat untuk kepentingan rakyat. Masa Orde Lama adalah masa pencarian bentuk implementasi Pancasila terutama dalam sistem kenegaraan. Pancasila diimplementasikan dalam bentuk yang berbeda-beda: Pertama, periode 1945-1950 dalam kehidupan politik, sila keempat yang mengutamakan musyawarah dan mufakat tidak dapat dilaksanakan, sebab demokrasi yang diterapkan adalah demokrasi parlementer, dimana presiden hanya berfungsi sebagai kepala negara, sedang kepala pemerintahan dipegang oleh Perdana Menteri. Kedua, periode 1950-1959, walaupun dasar negara tetap Pancasila, tetapi rumusan sila keempat bukan berjiwakan musyawarah mufakat, melainkan suara terbanyak (voting). Sistem pemerintahannya yang liberal sehingga lebih menekankan hak-hak individual. Ketiga, pada periode 1956-1965, dikenal sebagai periode demokrasi terpimpin. Demokrasi bukan berada pada kekuasaan rakyat sehingga yang memimpin adalah nilai-nilai Pancasila tetapi berada pada kekuasaan pribadi presiden Soekarno. Terjadilah berbagai penyimpangan penafsiran terhadap Pancasila dalam konstitusi. Akibatnya Soekarno menjadi otoriter, diangkat menjadi presiden seumur hidup, politik konfrontasi, menggabungkan Nasionalis, Agama, dan Komunis (Nasakom), yang ternyata tidak cocok bagi NKRI. Terbukti adanya kemerosotan moral di sebagian masyarakat yang tidak lagi hidup bersendikan nilai-nilai Pancasila.

Orde baru kemudian secara optimis ingin melaksanakan Pancasila dan UUD 1945 secara murni dan konsekuen sebagai kritik terhadap orde lama yang telah menyimpang dari Pancasila. Karena itu, hadirlah Pedoman Penghayatan dan Pengamalan Pancasila (P4). ${ }^{12}$ Tujuannya (1) agar Pancasila yang merupakan pandangan hidup Bangsa dan Dasar Negara RI dapat dihayati dan diamalkan secara nyata untuk menjaga kelestarian dan keampuhannya demi terwujudnya tujuan nasional serta cita-cita bangsa seperti tercantum dalam Pembukaan UUD Negara RI Tahun 1945. Untuk itu, Pemerintah membentuk pula Badan Pembinaan Pendidikan Pelaksanaan Pedoman Penghayatan dan Pengamalan Pancasila ( BP-7). ${ }^{13}$ Jadi, P4 dan BP-7 merupakan tonggak atau kekuatan dari implementasi Pancasila dalam kehidupan berbangsa dan bernegara.

Keberadaan P-4 yang didukung oleh BP-7 secara konseptual patut diapresiasi. Namun secara faktual, pancasila tidak menjangkar dalam kebijakan pemerintah. Pancasila bahkan ditafsirkan sesuai kepentingan kekuasaan dan tertutup bagi tafsiran lain. Pancasila juga

${ }^{12}$ P4 ditetapkanpada tanggal 22 Maret 1978 melalui Ketetapan MPR No. II/MPR/1978.

13 BP-7 dibentuk dengan surat Kepres No. 10 Tahun 1979. Bdk.,Joeniarto, Sejarah Ketatanegaraan Republik Indonesia, (Jakarta: Bumi Aksara, 2001), hlm. 149. 
"dikeramatkan" sebagai pembenaran untuk menjaga stabilitas nasional daripada sebagai ideologi yang membuka ruang kebebasan untuk berkreasi. Demokratisasi akhirnya tidak berjalan, dan pelanggaran HAM terjadi dimana-mana yang dilakukan oleh aparat pemerintah atau negara.

Kini tiba giliran Orde Reformasi untuk melakukan koreksi besar dan luas terhadap pelbagai penyelewengan yang dilakukan oleh Orde Baru. Sebagai misal, hak-hak rakyat mulai dikembangkan dalam tataran elit maupun dalam tataran warga masyarakat akar rumput. Rakyat bebas untuk berserikat dan berkumpul dengan mendirikan partai politik, LSM, dan lain-lain. Upaya koreksi ini diawali dengan melepaskan ikatan aturan dan pasungan kebijakan produk Orde Baru yang diduga sebagai penyebab utama tindakan penyelewenagan itu. Karena itu, Ketetapan MPR No. II/MPR/1978 tentang P4-pun dicabut. ${ }^{14}$ Hal itu berdampak langsung pada pembubaran institusi BP-7 sebagai institusi yang memiliki "kompetensi" dalam pembentukan karakter bangsa. ${ }^{15}$ Dengan dibubarkannya BP-7, praktis tidak ada lagi lembaga yang secara fungsional melakukan pemasyarakatan terhadap nilai-nilai luhur Pancasila, dan dalam implementasinya nilai-nilai luhur Pancasila menjadi semakin kurang dipahami, apalagi apalagi diamalkan sebagai landasan ideal dalam pembangunan bangsa.

\section{Radikalisme sebagai Ideologi Alternatif di Indonesia?}

Radikalisme merupakan gerakan sosial yang menolak secara menyeluruh tertib sosial yang sedang berlangsung dan ditandai oleh kejengkelan moral yang kuat untuk menentang dan bermusuhan dengan kaum yang memiliki hak-hak istimewa dan yang berkuasa. ${ }^{16}$ Radikalisme sering dimaknai berbeda diantara kelompok kepentingan. Dengan demikian, radikalisme merupakan gejala umum yang bisa terjadi dalam suatu masyarakat dengan motif beragam, baik sosial, politik, budaya maupun agama, yang ditandai oleh tindakan-tindakan keras, ekstrim, dan anarkis sebagai wujud penolakan terhadap gejala yang dihadapi.

Merujuk pada pemahaman di atas, maka dapat dikatakan bahwa radikalisme sudah lama bercokol di Indonesia. Sejak Indonesia berdiri sebagai bangsa dan negara yang merdeka radikalisme telah ada di Indonesia baik dalam tataran pemikiran maupun yang sudah meletus dalam aksi-aksi radikal. Oleh karena itu, sebenarnya radikalisme tumbuh berhimpitan dengan Idiologi Pancasila. Pada Orde Lama (1945-1965) radikalisme tampak dalam gerakan pemberontakan yang bersifat ideologis-politis yang berpuncak pada pemberontakan G/30/S/PKI. ${ }^{17}$ Selain itu, masa ini ditandai juga oleh gerakan-gerakan yang bernuansa kedaerahan yaitu pemberontakan PRRI dan Permesta sebagai gerakan separatis yang menghendaki pemisahan wilayah. Kondisi itu menimbulkan potensi intoleransi dan timbulnya distrust yang memengaruhi seseorang/sekelompok orang bersikap curiga dan bertindak radikal terhadap yang lain.

\footnotetext{
${ }^{14}$ Ketetapan MPR RI No. XVIII/MPR/1998 tentang pencabutan P4.

15 Bdk., Herbert Feith dan Lance Castle, (ed.), Pemikiran Politik Indonesia, (Jakarta: LP3ES 1988), hlm. xvii-xviii. Lihat juga, Moh. Mahfud M.D, Politik Hukum di Indonesia, (Jakarta: LP3ES, 1998), hlm. $200-201$.

${ }^{16}$ Sartono Kartodirdjo, Ratu Adil, (Jakarta: Sinar Harapan, 1985), hlm. 38.

${ }^{17}$ Pemberontakan DI/TII Jawa Barat (1949-1962), DI/TII Ibnu Hadjar di Kalimantan (1950;1959), DI/TII Jawa Tengah (1951-1954), DI/TII Kahar Muzakar di Sulawesi Selatan (1951-1965). DI/TII Daud Beureuh di Aceh (1953-1962).Sulasmono, Bambang S., (dkk), Mengkaji Ulang Dasar Negara Pancasila: Materi Pendidikan Pancasila, (Salatiga, P3KD Jurusan Studi PPKn- FKIP-UKSW, 2002).
} 
Sementara pada masa Orde Baru (1966-1998) pemberontakan yang bernuansa ideologi tidak mendapat tempat karena negara cukup kuat menghadapi pemberontakan-pemberontakan itu, seiring dengan menguatnya Pancasila sebagai dasar negara karena didukung sistem ketatanegaraan yang lebih menempatkan stabilitas keamanan dan politik. Sentimen kedaerahan dan kecemburuan terhadap daerah lain masih terjadi sehingga menjadi benih-benih terjadinya gerakan untuk memisahkan diri dari NKRI. Teror yang terjadi pada masa ini berupa gangguangangguan keamanan dan teritorial sehingga menuntut penguatan pada aspek keamanan dilakukan melalui penerapan Dwi Fungsi ABRI. Istilah radikalisme lebih menunjuk pada gerakan pengacau keamanan bersenjata.

Selanjutnya pada masa reformasi (1999 - 2018). Pergerakan radikalisme pada masa ini dapat dikelompokan berdasarkan masa pergerakan dan karakteristiknya sebagai berikut: Pertama, periode (1999-2004) paham radikalisme mulai tampak secara terang-terangan melalui aksi-aksi teror yang melanda kehidupan berbangsa dan bernegara. Ada nuansa politik, ekonomi, dan keamanan dalam konflik sebagaimana terjadi di Jawa, Ambon, Poso, Bali, Kalimantan (Sampit), dan daerah lain. Teror dalam periode ini ${ }^{18}$ lebih terwujud pada gerakan mengacau keamanan dan ketentraman masyarakat, walaupun ada tendensi ke arah politik. Sementara itu, dengan menguatnya kebebasan individu dalam interaksi berujung pada defisitnya sikap mental yang ideal seperti toleransi, kedamaian, kejujuran, keadilan dan kebenaran.

Kedua, periode 2005-2015. Sesuai dengan era globalisasi, maka radikalisme dalam periode ini memperlihatkan juga corak global, yaitu memanfaatkan jaringan internasional sehingga radikalisme tidak hanya berasal dari warga bangsa sendiri melainkan juga dari warga negara asing. Cara-cara yang digunakan untuk melakukan teror ${ }^{19}$ juga semakin canggih seiring dengan kemajuan teknologi modern. Aksi radikalisme dalam teror ini bukan hanya diarahkan pada pemerintah tetapi juga tempat-tempat vital dan kepada masyarakat dengan modus dan motivasi yang beragam pula.

Ketiga, Periode 2016-2018. Periode ini masih terjadi aksi teror di Indonesia. ${ }^{20}$ Pelbagai aksi teroris masa ini menunjukkan karakteristik yang berbeda dengan aksi teror sebelumnya: (1) Ada kecenderungan pergeseran dari sasaran obyek vital berupa perkantoran milik asing, istana negara dan tempat ibadah menjadi obyek markas kepolisian dan anggotanya; (2) Pelaku aksi

18 (i) Tahun 1999: Pemboman Toserba Ramayana Jakarta, Pemboman Mall kelapa Gading \& Pemboman Hayam Wuruk Plaza; (ii) Tahun 2000: Bom Kedubes Filipina (1/8), Bom kedubes Malaysia (27/8), Bom Bursa Effek (13/8), dan Bom malam natal (24/12); (iii) Tahun 2001: Bom Gereja Santa Anna dan HKBP (22/7), Bom Plaza Atrium Senen Jakarta (23/9), Bom Restoran KFC, Makasar (12/10) dan Bom Sekolah Australia (AIS) Pejaten, Jakarta; (iv) Tahun 2002: Bom Tahun Baru (1/1), Bom Bali (12/10) dan Bom restoran McDonald's (5/12); (v) Tahun 2003: Bom Kompleks Mabes Polri, Jakarta (3/2), Bom Bandara Soekarno-Hatta Jakarta (27/4), dan Bom JW Mariott (5/8); dan (v) Tahun 2004: Bom Palopo (10/1), Bom Kedubes Australia dan Ledakan Bom di Gereja Immanuel Palu, Sulawesi Tengah (12/12).

19 (i) Tahun 2005: Bom meledak di Ambon (21/3), Bom Tentena (28/5), Bom Pamulang (8/6), Bom Bali (1/10), Bom Bali II (1/10), dan Bom Palu (31/12); (ii) Tahun 2009: Bom Jakarta (17/7), dan (iii) Tahun 2015: Teror lewat SMS dan Isu tentang ISIS.

${ }^{20}$ (i) Tahun 2016: Bom Thamrin Jakarta Pusat (14/1), Bom Mapolresta Surakarta (5/7), Rencana aksi teror Batam (5/8), Aksi teror gereja Medan (28/8), Aksi teror gereja Samarinda (13/11), Mengancam objek vital negara (23/11), Rencana bom Istana (10/12), Aksi teror Solo (15/12); (ii) Tahun 2017: Bom panci meledak di lapangan terbuka di Kelurahan Arjuna, Kecamatan Cicendo, Bandung (27/2), Teror bom bunuh diri di Kampung Melayu (24/5), dan Polres Dharmasraya, Sumatera Barat dibakar dua terduga teroris (12/11); (ii) Tahun 2018: Teror di Mako Brimob, Depok, Jawa Barat (8-12/5), Bom di 3 Gereja di Surabaya (13/5), Bom di Rusunawa Wonocolo, Sidoarjo (13/5), dan Bom di Polrestabes Surabaya, Penyerangan terduga teroris ke Mapolda Riau (16/5). 
teror yang sebelumnya hanya dilakukan oleh kaum pria, tetapi masa ini aksi teror telah melibatkan kaum wanita dan anak-anak; (3) Aksi teror yang sebelumnya dilakukan berdasarkan garis komando, tetapi saat ini tanpa garis komando; dan (4) Aksi-aksi teror yang sebelumnya dilakukan dalam kelompok (jaringan) tetapi sekarang menjadi aksi terorisme individual atau (lone wolf terrorism) dan dilakukan secara sporadis.

Menjamurnya paham radikalisme di era reformasi ini, menunjukkan bahwa Indonesia merupakan lahan yang subur. Sebab pertumbuhan paham radikalisme tergantung di mana lahan ia ditabur. Jika ia ditabur di tanah gersang, maka paham itu sulit tumbuh, tetapi jika ia ditabur di lahan yang subur maka ia akan berakar dan cepat berkembang. Ladang subur tersebut adalah masyakarat yang dicemari oleh paham fundamentalisme ekstrim atau radikalisme. ${ }^{21}$ Hal ini merupakan fakta yang tak terbantahkan lagi bahwa di satu sisi gelombang globalisasi telah "mengekspor" paham radikalisme ke wilayah NKRI dan di sisi lain khususnya di era reformasi dengan segala kebebasan dan keterbukaan beberapa kelompok bangsa Indonesia sangat doyan "mengimpor" paham oplosan tersebut. ${ }^{22}$ Belakangan ini di tengah bangsa Indonesia amnesia terhadap Pancasila sebagai weltanschauung, kelompok itu ingin menggantikannya dengan ideologi/paham lain yang dianggap relevan untuk saat ini.

Beberapa faktor penyebab radikalisme, antara lain; pertama, faktor domestik, yakni kondisi dalam negeri seperti kemiskinan, ketidakadilan atau merasa kecewa dengan pemerintah. Kedua, faktor internasional, yakni pengaruh lingkungan luar negeri yang memberikan daya dorong tumbuhnya sentiment keagamaan seperti ketidakadilan global, politik luar negeri yang arogan, dan imperialisme modern negara adidaya. Ketiga, faktor kultural yang sangat terkait dengan pemahaman keagamaan yang dangkal dan penafsiran kitab suci yang sempit dan leksikal (harafiah). Sikap dan pemahaman yang radikal dan dimotivasi oleh berbagai faktor di tersebut menyebabkan seseorang menerima paham radikalisme dan memilih untuk bergabung dalam aksi dan jaringan terorisme.

\section{Mengagas Upaya Membumikan Pancasila untuk Meredam Radikalisme di Indonesia}

Pem-bumi-an Pancasila secara sistemik dan berkelanjutan merupakan satu-satunya cara yang efektif untuk membumihanguskan paham radikalisme di Indonesia. Upaya pembumian Pancasila dapat dilakukan dalam dan melalui tahap-tahap berikut:

\section{Memahami Pancasila secara baik dan benar}

Ketika bangsa ini ada dalam keadaan anomie, yakni terdapat kekosongan nilai serta mengalami amnesia terhadap nilai-nilai luhur yang ada dalam Pancasila, maka langkah penting yang perlu dilakukan adalah mengedukasi kembali warga bangsa ini dengan nilai-nilai Pancasila. Metode ini dalam bahasa BNPT (Badan Nasional Penanggulangan Terorisme) disebut Kontra radikalisasi, yakni upaya penanaman nilai-nilai ke-Indonesiaan serta nilai-nilai non-kekerasan.

${ }^{21}$ A.M. Hendroprioyono, Terorisme: Fundamentalis Kristen, Yahudi dan Islam, (Jakarta: Buku Kompas, 2009), hlm. 13.

${ }^{22}$ Kelompok itu antara lain: Hizbut Tahrir Indonesia (HTI), Majelis Mujahidin Indonesia (MMI), Front Pembela Islam (FPI), Gerakan Salafi, Laskar Jundullah, Lasykar Jihad, Gerakan Islam Ahlussunnah wal Jamaah, Jamaah Ansharut Tauhid (JAT), dan Negara Islam Indonesia (NII). 
Sehubungan dengan itu, pemerintah dalam hal ini MPR-RI periode 2009-2014 telah membentuk Badan Sosialisasi yang salah satu tugasnya memasyarakatkan empat pilar kebangsaan. ${ }^{23}$ MPR-pun sudah dan sedang melaksanakan tugasnya itu. Namun, mengingat pergerakan radikalisme yang sudah sangat masif, maka upaya pemerintah tersebut perlu didukung oleh semua pihak untuk mengedukasi warga bangsa ini dengan nilai-nilai Pancasila baik melalui pendidikan baik formal maupun non formal. Edukasi perlu diarahkan pada masyarakat umum melalui kerjasama dengan tokoh agama, tokoh pendidikan, tokoh masyarakat, tokoh adat, tokoh pemuda dan para stakehorlder lainnya; sehingga semua warga bangsa dan negara Indonesia dapat memahami secara baik dan benar nilai-nilai yang terkandung di dalam Pancasila.

Inti sari dari nilai-nila yang terkandung dalam Pancasila adalah, sebagai berikut: ${ }^{24}$ Sila Ketuhanan Yang Maha Esa: (a) Bangsa Indonesia adalah bangsa yang ber-Tuhan dan menolak paham anti Tuhan (atheisme); (b) Bangsa Indonesia wajib untuk menyembah Tuhannya dan beribadah menurut agama dan kepercayaannya masing-masing secara leluasa, berkeadaban, dan berkeadilan; (c) Bangsa Indonesia melaksanakan perintah agama dan kepercayaan masingmasing dengan tetap mengedepankan harmoni dalam kehidupan bermasyarakat, berbangsa dan bernegara; dan (d) Bangsa Indonesia menjalankan perintah agama dan kepercayaannya masingmasing dengan cara berbudi pekerti luhur dan sikap saling menghormati.

Sila Kemanusiaan yang Adil dan Beradab: (a) Indonesia adalah negara bangsa (nation state) yang merdeka, bersatu dan berdaulat menuju kepada kekeluargaan bangsa-bangsa di dunia; (b) Bangsa Indonesia adalah bangsa yang menghendaki pergaulan bangsa-bangsa di dunia dengan prinsip saling menghormati nilai-nilai nasionalisme setiap bangsa yang tumbuh subur dalam taman sarinya pergaulan bangsa-bangsa di dunia; dan (c) Bangsa Indonesia merupakan bagian dari kemanusiaan universal yang menjunjung tinggi HAM dan mengembangkan persaudaraan dunia berdasarkan nilai-nilai keadilan dan keadaban.

Sila Persatuan Indonesia: (a) Kita mendirikan suatu Negara Kebangsaan Indonesia untuk keseluruhan rakyat Indonesia, bukan negara untuk satu kelompok, maupun untuk satu golongan; (b) Persatuan Indonesia bernafaskan semangat kebangsaan yang melindungi segenap bangsa dan seluruh tumpah darah Indonesia yang senasib dan sepenanggungan dalam bingkai NKRI; (c) Persatuan Indonesia adalah sikap kebangsaan yang saling menghormati perbedaan dan keberagaman masyarakat dan bangsa Indonesia; dan (d) Kebangsaan Indonesia bukanlah kebangsaan yang sempit dan berlebihan (chauvinisme) melainkan kebangsaan yang menghormati eksistensi bangsa-bangsa lain.

Sila Kerakyatan yang Dipimpin oleh Hikmat Kebijaksanaan dalam Permusyawaratan/ Perwakilan: (a) Negara Indonesia adalah negara demokrasi yang mengakui dan menjunjung tinggi kedaulatan rakyat; (b) Bangsa Indonesia memelihara dan mengembangkan semangat musyawarah untuk mufakat dalam pengambilan setiap keputusan; (c) Bangsa Indonesia meyakini jalan musyawarah untuk mufakat dan menjaga keselamatan dan keberlangsungan bangsa dan negara; (d) Bangsa Indonesia tidak mengenal sistem diktator mayoritas dan tirani minoritas; dan (e) Bangsa Indonesia dalam mengambil keputusan senantiasa dipimpin oleh

${ }^{23}$ Pembentukan Badan Sosialisasi yang salah satu tugasnya memasyarakatkan empat pilar kebangsaan (Pancasila, UUD Negara RI 1945, NKRI dan Bhineka Tunggal Ika) sesuai dengan amanat Pasal 5 Undang-Undang No. 17 Tahun 2014 jo Undang-Undang No. 42 Tahun 2014 tentang MPR, DPR, DPD, dan DPRD.

${ }^{24}$ MPR RI, Bahan Tayangan Materi Sosialisasi Empat Pilar MPR RI, (Jakarta: 2018), hlm. 19-23. 
nilai-nilai ketuhanan, kemanusiaan, persatuan, dan keadilan dalam semangat hikmat kebijaksanaan dalam permusyawaratan untuk mewujudkan keadilan.

Sila Keadilan Sosial bagi Seluruh Rakyat Indonesia: (a) Negara Indonesia didirikan untuk bersungguh-sungguh memajukan kesejahteraan bagi seluruh rakyat Indonesia baik lahir maupun batin; (b) Dalam Negara Indonesia setiap warga negara berhak untuk mendapatkan pekerjaan dan penghidupan yang layak, bermartabat dan berkeadilan bagi kemanusiaan; dan (c) Negara Indonesia wajib menjamin setiap warga negara untuk mendapatkan pendidikan, pekerjaan dan penghidupan yang layak, bermartabat dan berkeadilan.

\section{Mencintai Pancasila secara sungguh-sungguh}

Proses edukasi yang efektif diharapkan tidak hanya sampai pada tahap memahami secara kognitif, tetapi harus sampai pada penerimaan secara afektif. Artinya, penanaman nilai-nilai Pancasila harus dapat memengaruhi keadaaan perasaan dan emosi bangsa Indonesia. Tanggapan terhadap nilai-nilai Pancasila dalam proses edukasi harus dapat memberikan keterarahan emosional (empatisme) kepada seluruh masyarakat Indonesia untuk tetap mencintai Pancasila sebagai leitstar dalam kehidupan bermasyarakat, berbangsa dan bernegara.

Dalam keterarahan emosional bangsa Indonesia untuk selalu mencintai Pancasila, sebenarnya sudah mulai terjadi proses internalisasi nilai-nilai hakiki yang terkandung di dalam Pancasila (ketuhanan, kemanusiaan, persatuan, kerakyatan dan keadilan). Proses internalisasi yang terus-menerus akan membentuk watak/karakter/kepribadian (skill) bangsa. Jika demikian nilai-nilai Pancasila tidak hanya menjadi "milik" bangsa Indonesia tetapi telah menjadi ciri khas watak/karakter/kepribadian bangsa Indonesia. Dalam pengertian ini, Pancasila dan bangsa Indonesia tidak bisa dilepas-pisahkan: "bangsa Indonesia sama dengan Pancasila" dan "Pancasila sama dengan bangsa Indonesia".

Pada aras ini bangsa Indonesia sebenarnya sudah sampai pada tahap kematangan atau kedewasaan emosional. Watak/karakter/kepribadian bangsa menjadi basis moral (etika) untuk memfilter dan menjustifikasi setiap paham yang terus menggempur bangsa ini. Dengan basis moral yang baik bangsa Indonesia dapat menilai mana yang sesuai dengan nilai-nilai Pancasila dan budaya bangsa dan mana yang tidak sesuai bahkan bertentangan dengan nilai-nilai Pancasila (nilai ketuhanan, nilai kemanusiaan, nilai persatuan, nilai kerakyatan, dan nilai keadilan). Halhal yang sesuai dengan-nilai Pancasila dapat diterima untuk mendukung pertumbuhan dan perkembangan bangsa dan negara dalam percaturan tata dunia yang kian mengglobal. Sementara paham yang tidak sesuai bahkan jelas-jelas bertentangan dengan nilai-nilai Pancasila harus ditolak karena dapat mengancam dan menghancurkan tatanan kehidupan bermasyarakat, berbangsa dan bernegara.

Mengingat pergerakan paham radikalisme yang kian masif merasuki kehidupan bermasyarakat, berbangsa dan bernegara di Indonesia, maka perlu upaya konkrit untuk memfilter bangsa ini dari bahaya radikalisme. Salah satu upaya yang dapat dilakukan adalah melalui program deradikalisasi. Program deradikalisasi harus diarahkan secara fokus kepada tiga kelompok sasar: Pertama, masyarakat umum, dengan tujuan untuk melindungi masyarakat agar tidak mengikuti pandangan-pandangan keagamaan yang ekslusif dan puritan dan agar tidak ikut terlibat dalam aksi-aksi radikal dan intoleran. Perhatian pada kelompok ini harus lebih besar 
diarahkan pada kelompok dengan kategori rentan seperti generasi muda ${ }^{25}$ dan kaum marjinal (miskin dan menderita). Untuk hal ini perlu dibentuk kelompok creative minority. ${ }^{26}$ Kelompok creative minority ialah kelompok kaum pemimpin, yang merupakan golongan kecil, namun karena superioritas jiwa dan rohnya serta kekuatan dan keteguhan keyakinannya sanggup menunjukkan jalan dan membimbing massa yang pasif, kehilangan arah, dan mengalami kebingungan. Kehadiran kelompok creative minority dirasakan semakin penting mengingat dewasa ini, paham-paham transnasional juga sudah semakin massif membanjiri literasi masyarakat lewat berbagai saluran informasi.

Kedua, kelompok radikal (pendukung, inti dan militan) yang dimaksudkan untuk menjinakkan sejumlah ideologi radikal yang diyakini oleh mereka dengan menggunakan counter narative. Salah satu dari ideologi radikal yang harus dijinakkan adalah ajaran mati syahid dan janji-janji surga yang disalahpahami oleh para teroris. Ketiga, kelompok jihadis atau teroris. Program deradikalisasi untuk kedua kelompok yang terakhir ini merupakan mega proyek yang harus segera dilakukan bangsa dan negara Indonesia saat ini. Program ini harus dilakukan secara sistematis sehingga dapat memutuskan mata rantai para mantan teroris dari kelompoknya, hingga mereka tidak kembali melakukan aksi kekerasan. Pekerjaan besar yang perlu dilakukan di sini yaitu mengkaji pola pikir yang paling dalam dari ideologi radikal global dan membuktikan kelemahan dalil-dalil untuk selanjutnya dipatahkan dengan dalil-dalil yang bersumber dari nilai-nilai Pancasila sebagai Ideologi Bangsa dan Negara-RI. Tujuan dari deradikalisasi agar kelompok inti, militan simpatisan dan pendukung meninggalkan cara-cara kekerasan dan teror dalam memperjuangkan misinya serta memoderasi paham-paham radikal mereka sejalan dengan semangat kelompok moderat dan sesuai dengan nilai-nilai Pancasila serta misi-misi kebangsaan yang memperkuat NKRI.

Jadi, kunci utama dari aktor deradikalisasi adalah pemerintah. Dengan segenap agenda pembangunan yang dijalankannya, program-program pemerintahan yang mendorong pembangunan masyarakat yang toleran, moderat dan rukun harus diintensifkan sebagai bagian dari upaya menekan laju radikalisme dan terorisme. ${ }^{27}$ Karena deradikalisasi tak hanya dimaksudkan untuk menyelamatkan masyarakat luas dari aksi-aksi radikalisme dan terorisme, melainkan juga dimaksudkan untuk menyelamatkan keluarga pelaku aksi kekerasan bahkan juga diri pelaku.

Satu hal penting yang perlu disadari bahwa deradikalisasi dalam praktiknya akan mengalami banyak hambatan karena yang dihadapi adalah "menjinakkan" pemikiran. Terlepas dari ini semua, akan membuka banyak pemikiran bahwa deradikalisasi harus dijalankan tentu dengan berbagai hambatan yang harus diupayakan bisa diatasi, karena tujuan utamanya adalah menjaga tegaknya kehidupan berbangsa dan bernegara.

${ }^{25}$ Masa transisi krisis identitas kalangan pemuda berkemungkinan untuk mengalami apa yang disebut Quintan Wiktorowicz (2005) sebagai cognitive opening (pembukaan kognitif), sebuah proses mikro-sosiologis yang mendekatkan mereka pada penerimaan terhadap gagasan baru yang lebih radikal. Alasan-alasan seperti itulah yang menyebabkan mereka sangat rentan terhadap pengaruh dan ajakan kelompok radikalisme dan terorisme.

${ }^{26}$ Istilah creative minority yang dipinjam dari ahli sejarah berkebangsaan Inggris yang terkenal, Arnold J. Toynbee, dalam bukunya "A Study of History". Notohamidjojo, O. Kreativitas Yang Bertanggungjawab, (Universitas Kristen Satya Wacana Salatiga, 2011).

${ }^{27}$ Ismail Hasani \& Bonar Tigor Naipospos (eds.), Dari Radikalisme Menuju Terorisme : Studi Relasi dan Transformasi Organisasi Islam radikal di Jawa Tengah dan DI Yogyakarta, (Yogyakarta: Pustaka Masyarakat Setara, 2012), hlm. 201. 


\section{Menerapkan nilai-nilai Pancasila dalam kehidupan berbangsa dan bernegara}

Dalam proses membumikan Pancasila, satu hal yang tidak boleh dilupakan adalah meningkatkan relevansi nilai-nilai Pancasila dalam kehidupan bermasyarakat, berbangsa dan bernegara, sehingga masyarakat bukan saja memahami secara kognitif dan menerimanya secara afektif, tetapi harus menindaklanjutinya secara psikomotoris. Karena itu nilai-nilai Pancasila sangat mutlak untuk diaplikasikan secara konkret dalam kehidupan bermasyarakat, berbangsa dan bernegara. Jadi, Pancasila sebagai pantulan cita-cita dan kehendak bersama, mengharuskan nilai-nilai Pancasila hidup dalam realita dan tidak hanya sebatas retorika/verbalisme di pentas politik. ${ }^{28}$

Aktualisasi nilai-nilai Pancasila dapat dibedakan menjadi dua macam, yaitu aktualisasi subjektif yaitu realisasi pada setiap individu, dan aktualisasi objektif yaitu realisasi dalam segala aspek kenegaraan dan hukum. Aktualisasi Pancasila subjektif lebih bersifat masif karena pelaksanaan nilai Pancasila diletakkan pada individu masing-masing pada warga negara Indonesia. Sedangkan, aktualisasi objektif adalah pelaksanaan dalam bentuk realisasi dalam setiap aspek penyelenggaraan negara baik, bidang legislatif, eksekutif, dan yudikatif, serta semua bidang kenegaraan terutama realisasinya dalam bentuk peraturan perundang-udangan Indonesia serta turunannya.

Aktualisasi Pancasila yang subjektif adalah pelaksanaan pada setiap pribadi perseorangan, setiap warganegara, setiap individu, setiap penduduk, setiap penguasa dan setiap orang Indonesia. Aktualisasi Pancasila pada ranah subjektif ini justru lebih penting karena realisasi yang subjektif merupakan persyaratan bagi aktualisasi Pancasila yang objektif. ${ }^{29}$ Gagasan mengaktualisasikan Pancasila perlu adanya peran pemerintah baik eksekutif, legislatif dan yudikatif melalui sebuah kebijakan dan pengamalan mulai dari pusat sampai ke daerah. Sehingga Pancasila tidak hanya indah dalam kata-kata, namun baik dalam implementasi dalam kehidupan masyarakat, berbangsa dan bernegara.

Aktualisasi nilai-nilai Pancasila harus menjadi gerakan bersama yang terencana dengan baik sehingga tidak hanya menjadi slogan politik tanpa makna/implementasi. Melalui gerakan bersama aktualisasi nilai-nilai Panasila bukan saja akan menghidupkan kembali memori publik tentang dasar dan ideologi negaranya. Tetapi juga akan menjadi solusi dan inspirasi bagi para penyelenggara negara dari tingkat pusat sampai dengan tingkat daerah dalam menjalankan roda pemerintahan yang telah diamanahkan rakyat.

Akhirnya aktualisasi Pancasila secara subjektif akan melahirkan aktualisasi Pancasila yang obyektif, yang tampak dalam pelbagai program dan kebijkaan pemerintah. Dalam logika ini tentu program dan kebijakan pemerintah tidak akan beranjak jauh dari nilai-nilai Pancasila. Itu berarti produk kebijakan pemerintah baik dalam ranah politik, hukum, maupun ekonomi harus memiliki cita rasa Pancasila. Sebab pemerintah (eksekutif, legislatif dan yudikatif) sendiri merupakan organ negara yang berkarakter Pancasila (Pancasilais). ${ }^{30}$ Hal ini dapat mengurangi tensi frustrasi (frustration) dan rasa tidak percaya (distrust) masyarakat terhadap pemerintah yang selama ini telah menjadi salah satu faktor penyebab munculnya radikalisme di Indonesia.

${ }^{28}$ Y. Latif, Negara Paripurna, Historisitas, Rasioalitas, dan Aktualitas Pancasila, (Jakarta: Gramedia, 2011), hlm. 32.

${ }^{29}$ Notonagoro, Pancasila Secara Utuh Populer, (Jakarta: Pancoran Tujuh, 1975), hlm. 44.

${ }^{30}$ Kristoforus Kopong, Membumikan Op.Cit., hlm. 256. 
Dalam konteks belajar bersama, sikap dan tindakan pemerintah yang memiliki cita rasa Pancasila tentu dapat pula menjadi teladan yang baik bagi warga masyarakat. Dengan metode ini, warga masyarakat akan belajar untuk lebih bersikap toleran, adil, jujur, bijaksana, saling menghormati dan saling membantu dalam hidup bersama. Artinya, Pembumian Pancasila harus menyentuh tataran value, norms sampai behaviour setiap individu yang kemudian memberikan multiplier effect berupa terwujudnya masyarakat yang aman, tenteram dan damai. Di titik ini Pancasila tidak lagi hanya sekedar menjadi bingkai penghias dinding instansi pemerintah dan lampiran pidato para pejabat publik dalam momen kenegaraan tetapi benar-benar bersifat fungsional karena menjangkar dan hidup di tengah masyarakat, bangsa dan negara Indonesia.

Dalam konteks Kabupaten Ende, ketika kita menyinggung soal membumikan Pancasila, maka pikiran kita langsung tertuju pada situs Bung Karno di Jln. Perwira dan Taman Renungan Bung Karno di Jln. Sukarno. Sebagai "rahim Pancasila" apa relevansi Pembumian Pancasila bagi masyarakat Kabupaten Ende? Sebagai kota yang paling plural di Flores, warga Kabupaten Ende perlu menjaga toleransi antar-suku, antar-agama, antar-ras dan antar-golongan. Ende harus menjadi ikon toleransi bagi bangsa dan negara Indonesia. Jangan pernah ada sikap intoleransi di "rahim Pancasila", karena intoleransi adalah titik awal radikalisme. Olehnya, intoleran "di rahim" Pancasila haram hukumnya.

Dalam pemahamannya yang lebih luas, pemerintah daerah (eksekutif, legislatif dan yudikatif) sudah seharusnya berkarakter Pancasila. Hindari kebijakan yang tidak populis dan tindakan yang tidak terpuji seperti korupsi, kolusi, dan nepotisme (KKN) serta sikap arogan dalam menjalankan fungsi pemerintahan; sehingga tidak menimbulkan potensi intoleransi seperti frustrasi (frustration) dan rasa tidak percaya (distrust) masyarakat terhadap pemerintah. Karena di "rahim Pancasila" sikap-sikap yang tidak terpuji itu sama haramnya dengan intoleransi dan radikalisme.

Hal lain yang perlu dilakukan dalam "rahim Pancasila" ini adalah meradikalisasikan Pancasila dalam arti positif ${ }^{31}$, yaitu penjangkaran atau pengakaran lebih dalam pada seluruh lapisan masyarakat Kabupaten Ende. Hal konkret yang dapat dilakukan oleh Pemerintah Daerah adalah menata secara lebih baik lagi dua tempat bersejarah di Kota Ende, yaitu Situs Bung Karno dan Taman Renungan Pancasila, sehingga menjadi tempat yang layak bagi masyarakat Kabupaten Ende, khususnya pelajar dan mahasiswa untuk belajar nilai-nilai Pancasila, nilai kebangsaan dan multikultural lainnya. Untuk itu perlu disiapkan tempat baca berupa rumah/pondok literasi yang dilengkapi dengan pelbagai referensi tentang Pancasila, wawasan kebangsaan dan multikultural lainnya. Melalui cara ini masyarakat Kabupaten Ende dapat belajar untuk tahu (learning to know) Pancasila, belajar untuk melakukan/menerapkanya (learning to do), belajar untuk menjadi (learning to be) pribadi yang Pancasilais, dan belajar untuk hidup bersama (learning to live to gether) dalam kebinekaan yang harmonis. Dalam dan melalui "radikalisasi Pancasila" seperti ini, kita dapat meredam paham radikalisme dan dengan demikian Pancasila dan rahimnya memperoleh kesejatiannya di Kabupaten Ende, sehingga Ende-Lio pun dapat menjadi Sare Pawe.

\section{Penutup}

${ }^{31}$ Istilah Radikalisasi Pancasila dikemukakan oleh Kuntowijoyo dan dikutip penulis dari tulisan Yudi Latif yang berjudul "Sukarno sebagai Penggali Pancasila" dalam Prisma Majalah Pemikiran Sosial Ekonomi berjudul: Soekarno-Membongkar Sisi-sisi Hidup Putra Sang Fajar, Edisi Khusus/Volume 32, No. 2 \& No. 3 Tahun 2013, hlm. 42. 
Sejak awal berdirinya NKRI, the founding fathers sungguh menyadari bahwa bangsa Indonesia merupakan bangsa yang majemuk karena terdiri atas berbagai suku bangsa, adat istiadat, budaya, bahasa daerah, serta agama yang berbeda-beda. Bangsa yang majemuk ini hanya dapat berdiri kokoh di atas dasar Pancasila. Nilai-nilai Pancasila (ketuhanan, kemanusiaan, persatuan, kerakyatan dan keadilan) yang bersifat abstrak-umum-universal mampu mempersatukan bangsa ini hingga mencapai usianya ke-73 tahun.

Berhadapan dengan radikalisme dengan segala kompleksitasnya Pancasila perlu dibumi-kan kembali untuk menyadarkan bangsa Indonesia dari keadaan amnesianya terhadap nilai-nilai Pancasila. Untuk itu perlu dilakukan langkah konkret dengan berusaha memahami Pancasila secara baik dan benar (utuh-menyeluruh), sehingga dapat mencintai secara sungguhsungguh dan melaksanakannya dalam kehidupan bermasyarakat, berbangsa dan bernegara. Semua ini tentu membutuhkan komitmen dan keterlibatan seluruh komunitas masyarakat untuk menolak radikalisme dan aksi-aksi terorisme demi keberlangsungan kehidupan bangsa dan negara tercinta yang damai, adil dan sejahtera.

\section{Daftar Kepustakaan}

Hasani, Ismail \& Bonar Tigor Naipospos (eds.), Dari Radikalisme Menuju Terorisme : Studi Relasi dan Transformasi Organisasi Islam radikal di Jawa Tengah dan DI Yogyakarta, Yogyakarta: Pustaka Masyarakat Setara, 2012

Hendroprioyono, A.M., Terorisme: Fundamentalis Kristen, Yahudi dan Islam, Jakarta: Buku Kompas, 2009

Feith, Herbert dan Lance Castle, (ed.), Pemikiran Politik Indonesia, Jakarta: LP3ES 1988

Joeniarto, Sejarah Ketatanegaraan Republik Indonesia, Jakarta: Bumi Aksara, 2001

Kartodirdjo, Sartono, Ratu Adil, Jakarta: Sinar Harapan, 1985

Kepres No. 10 Tahun 1979 tentang Badan Pembinaan Pendidikan Pelaksanaan Pedoman Penghayatan dan Pengamalan Pancasila

Ketetapan MPR No. II/MPR/1978 tentang Pedoman Penghayatan dan Pengamalan Pancasila

Kopong, Kristoforus, Membumikan Pancasila, Mengurai Benang Kusut NKRI, Yogyakarta: WR, 2015

----------, Berselancar ke Ranah Konstitusi, Mengenal dan Memahami Konstitusi Indonesia (UUD 1945) dari Proses Pembentukan sampai dengan Perubahannya, Yogyakarta: WR, 2017

Latif, Yudi, Negara Paripurna, Historisitas, Rasioalitas, dan Aktualitas Pancasila, Jakarta: Gramedia, 2011

----------, "Sukarno sebagai Penggali Pancasila" dalam Prisma Majalah Pemikiran Sosial Ekonomi berjudul: Soekarno-Membongkar Sisi-sisi Hidup Putra Sang Fajar, Edisi Khusus/Volume 32, No. 2 \& No. 3 Tahun 2013

Mahfud, Moh., Politik Hukum di Indonesia, Jakarta: LP3ES, 1998

MPR RI, Bahan Tayangan Materi Sosialisasi Empat Pilar MPR RI, Jakarta: 2018 
Notonagoro, Pancasila Secara Utuh Populer, Jakarta: Pancoran Tujuh, 1975

Oesman, Oetojo dan Alfian (peny.), Pancasila Sebagai Ideologi, Jakarta: BP7 Pusat, 1991

O., Notohamidjojo, Kreativitas Yang Bertanggungjawab, Universitas Kristen Satya Wacana Salatiga, 2011

Pasha, Mustafa Kamal, dkk., Pancasila Dalam Tinjauan Historis, Yuridis, dan Filosofis, Yogyakarta: Citra Karsa Mandiri, 2003

Soerjanto Poespowardojo, Filsafat Sebuah Pendekatan Sosio Budaya, Jakarta: Gramedia, 1988

Suswarno, P.J., Pancasila Budaya Bangsa Indonesia, Yogyakarta: Kanisius, 1993

Toyibin, M. Aziz dan A. Kosasih Djahiri dalam buku Pendidikan Pancasila, Jakarta: PT. Rineka Cipta, 1997

Undang-Undang No. 17 Tahun 2014 jo Undang-Undang No. 42 Tahun 2014 tentang MPR, DPR, DPD, dan DPRD.

Wiktorowicz, Quintan, Radical Islam Rising: Muslim Extrism in the West, United States Of America: Rowman \& Litlefield Publishers Inc, 2005

Yamin, Muhammad, Naskah Persiapan UUD 1945, Jakarta : PT. Yayasan Prapantja, 1959 